\title{
CORRELATION STUDY OF PLAQUE AND GINGIVAL INDEXES OF MOTHERS AND THEIR CHILDREN
}

\author{
ESTUDO DA CORRELAÇÃO DOS ÍNDICES DE PLACA E GENGIVAL EM MÃES E FILHOS
}

\author{
Ana Cláudia Durante RAMIRES-ROMITO ${ }^{1}$, Luciana Butini OLIVEIRA², Giuseppe Alexandre ROMITO \\ Márcia Pinto Alves MAYER ${ }^{4}$, Célia Regina Martins Delgado RODRIGUES ${ }^{5}$
}

\author{
1- DDS, MSc, PhD, Graduate student (Doctor degree), Department of Dental Materials, University of São Paulo. \\ 2- DDS, MSc, PhD, Graduate student (Doctor degree), Department of Orthodontics and Pediatric Dentistry, University of São Paulo. \\ 3- DDS, MSc, PhD, Assistant Professor, Department of Stomatology, University of São Paulo. \\ 4- DDS, MSc, PhD, Associate Professor, Department of Microbiology, University of São Paulo. \\ 5- DDS, MSc, PhD, Associate Professor, Department of Orthodontics and Pediatric Dentistry, University of São Paulo.
}

Corresponding adress: Dra. Célia Regina Martins Delgado Rodrigues - Universidade de São Paulo - Departamento de Ortodontia e Odontopediatria Av. Prof Lineu Prestes, 2227, 05508-900 São Paulo, SP, Brasil. - Tel/Fax: +55-11-3091-7854. E-mail: celiadr@usp.br

Received: April 26, 2004 - Modification: June 21, 2004 - Accepted: April 15, 2005

\begin{abstract}
$T_{\text {r }}$

Lhis study aimed to compare the periodontal condition between plaque and gingival indexes in 30 pairs of mother and child with mixed dentition, as well as to correlate the findings with some of their social and oral hygiene habits. Mother's and child's plaque and gingival indexes were recorded during clinical examination. Periapical and bitewing radiographs were taken in order to assess the presence of any pathologic bone loss. Questionnaires answered by the mothers were used to collect information regarding the mother's and the child's habits of tooth hygiene and the mother's job, instruction level and family income. The data collected from the mothers' group and from the children's group were statistically analyzed both separately and with the two groups together. From the statistical analyses (Pearson correlation test, student test and Covariance analysis), it was possible to conclude that there was a greater correlation between the plaque and gingival indexes in the mothers' group than in the children's group. No significant correlation between plaque and gingival indexes could be found between the pairs. Also, bone loss and plaque and gingival indexes in the children did not show any correlation. The mothers' plaque indexes increased with age and decreased when they flossed everyday and when they had a job. The children's plaque indexes were lower when they had their tooth hygiene done by their mothers, when the latter had declared that they flossed their children's teeth everyday, and also when the mothers had a job. Children's gingival indexes increased with age and decreased when they brushed their teeth more often, when their mothers had a job and when their mothers declared they are used to flossing every day.

Uniterms: Periodontal disease; Plaque and gingival indexes; Oral hygiene habits; Mothers; Children.
\end{abstract}

\footnotetext{
RESUMO

O

objetivo deste estudo foi comparar a condição periodontal em 30 pares de mães e crianças com dentição mista, através dos índices de placa e gengival, bem como verificar sua correlação com alguns aspectos sociais e hábitos de higiene oral. No exame clínico foram registrados o índice de placa (IP) e índice gengival (IG) e, em seguida, foram realizadas tomadas radiográficas periapicais e interproximais que possibilitaram avaliar a possível presença de perdas ósseas em mães e crianças. Através de questionários, foram colhidas informações a respeito dos hábitos de higiene oral das mães e crianças, nível de escolaridade da mãe, se a mãe trabalhava fora e a renda familiar. Após análise estatística (Teste de Correlação de Pearson; test t de Student; Análise de Covariância), concluiu-se que houve maior correlação entre os índices de placa e gengival composto por adultos do que no grupo de crianças. Não foi encontrada correlação significante entre os índices de placa e gengival nos pares de mães e crianças. Não foi encontrada nenhuma correlação significante entre perda óssea e os índices de placa ou gengival dos pares. O índice de placa total das mães aumentou a idade e diminuiu quando a mãe utilizava fio dental diariamente e quando esta trabalhava fora. O índice gengival total das mães também foi reduzido quando elas trabalhavam fora. Houve redução no índice de placa total da criança quando a mãe a auxiliava durante a escovação, quando a mãe utilizava fio dental diariamente e quando esta trabalhava fora. O índice gengival total da criança foi maior com o aumento da idade e foi reduzido com aumento da sua freqüência de escovação, quando a mãe utilizava fio dental diariamente e quando a mãe trabalhava fora. Unitermos: Doença periodontal; Índices de placa e gengival; Hábitos de higiene oral; Mães; Crianças.
} 


\section{INTRODUCTION}

Periodontal disease is one of the main causes for tooth loss. Damage to tissues occurs due to an interaction of specific bacterial and host's factors (Bimstein, et al. ${ }^{6}$ 1996). The role of dental plaque as the primary etiologic agent in gingivitis has been demonstrated in classic studies of experimental gingivitis in adults (Theilade, et al. $\left.{ }^{24}, 1966\right)$ and children (Mackler and Crawford $^{12}$, 1973; Matsson ${ }^{13}$, 1978; Parfitt ${ }^{17}$, 1957). Little correlation between plaque presence and gingivitis has been reported in pre-school children (Mackler and Crawford ${ }^{12}$, 1973; Matsson and Goldberg ${ }^{14}$, 1985; Parfitt $^{17}$, 1957), probably due to age-related bacteriological differences and/or differences in the immune response between children and adults (Bimstein and Ebersole 4 , 1989; Matsson ${ }^{13}$, 1978; Morinushi, et al. ${ }^{16}$, 2000; Parfitt $^{17}$, 1957). Furthermore, a hormonal influence is strongly suggested on the gingival inflammatory process concomitant to pre-puberty and puberty (Parfitt ${ }^{17}, 1957$; Peretz, et al. ${ }^{18}$, 1993; Peretz, et al. ${ }^{19}$, 1996). During the mixed dentition, similar amounts of gingival inflammation are observed in permanent and deciduous teeth (Matsson and Goldberg ${ }^{14}$, 1985; Ramberg, et al. ${ }^{21}$, 1994).

Although the severity of gingivitis is less intense in children than in adults (Mackler and Crawford ${ }^{12}$, 1973; Matsson and Goldberg $\left.{ }^{14}, 1985\right)$, periodontitis may occur in children and adolescents (Albandar, et al. ${ }^{1}$, 1995; Bimstein, et al. 6 ; 1996). The early colonization by highly virulent organisms and/or an impaired host response are associated to the etiology of early-onset periodontitis, although local factors such as presence of carious cavities may also influence attachment loss (Albandar, et al. ${ }^{1}$, 1995). The familial environment has been considered as the main source of pathogenic organisms and also influences the establishment of long-lasting habits, including tooth cleaning ( $\mathrm{Li}$ and Caufield ${ }^{9}$, 1995; Von Troil-Lindén, et al. ${ }^{25}$, 1995).

Studies have demonstrated the similarity of the microbiota between mother/child, considering both cariogenic or periodontal pathogenic organisms such as Streptococcus mutans and Prevotella intermedia (Caufield, et al. ${ }^{7}$, 1993; Könönen, et al. ${ }^{8}$; 1994; Matsson $^{13}$, 1978; Matsson and Goldberg $\left.^{15}, 1986\right)$. The periodontal conditions of mothers and their children may also correlate (Löe and Silness ${ }^{10}$, 1963). However, very few studies correlated the clinical variables in pairs of mother and their children with mixed dentition, with reported habits.

The aim of the present study was to assess the periodontal conditions in terms of plaque and gingival indexes and alveolar bone loss of mothers and children with mixed dentition. The clinical findings were also correlated with reported social conditions and oral hygiene habits.

\section{MATERIALAND METHODS}

The study group was formed by thirty pairs of mothers (29 to 49 years old, mean $38.50 \pm 5.17$ ) and children with mixed dentition ( 7 to 11 years old, mean $8.67 \pm 0.92$ ). The children were selected among those selected for treatment at the
Department of Orthodontics and Pediatric Dentistry at the Dental School of University of São Paulo. The patients had not taken antibiotics at least for the last three months before the exam. The procedures, possible discomforts or risks, as well as the benefits of this study were fully explained to the subjects involved, and their informed consent was obtained prior to the investigation. This study was reviewed and approved by Ethics Committee of the University of São Paulo.

Information about medical and dental history of each subject was obtained during the anamnesis. A dentist interviewed children's mothers about their oral hygiene habits and social economical conditions using a questionnaire.

Mothers who did not present first molars and incisors were excluded from the study group. Children should have the four first permanent molars $(n=4)$ at least with two thirds erupted, maxillary and mandibular incisors fully erupted, no proximal caries lesion (checked through bite-wing radiographs) and no fistula. Deciduous teeth with more than one third of root resorption were not considered.

One trained examiner performed the all clinical examination. Gingival inflammation was determined by Löe and Silness ${ }^{10}$ (1963), and dental plaque and gingival indexes were assessed according to Silness and Lö $\mathrm{e}^{22}$ (1964). Four surfaces per tooth (buccal, lingual, mesial and distal) were examined in every permanent and deciduous tooth (except for third molars in the mothers group). Plaque and gingival indexes were calculated separately for every mother and child.

Two X-rays from molar region (bitewing) and two from the anterior region (periapical) were taken from each subject to assess the distance from the cementoenamel junction to the alveolar bone crest (CEJ-ABC distance). Measurements were made by transferring the radiographic images to a computer program (Image Lab $®$ - Oral Pathology Department Program - Dental School, University of São Paulo, Brazil).

Pearson's correlation test was done in order to determine the correlation between: 1) plaque and gingival indexes of mother/child pairs; 2) CEJ-ABC distances and plaque and gingival indexes (measured only in mothers, on the mesial surfaces of maxillary central incisors and on first molars); and 3) The mean value of all CEJ-ABC distances measured in mothers and children's total gingival indexes.

The influence of some behavioral and social factors in plaque and gingival indexes of mothers and children was assessed by using the covariance analysis tests.

Results at the $5 \%(\mathrm{p}<0.05)$ level of probability were considered statistically significant.

\section{RESULTS}

The mean values of plaque and gingival indexes from the children and their mothers are shown in Table 1. Correlation analysis between plaque and gingival indexes in the group of children (C) and in the group of mothers (M) are shown in Table 2. Significant correlations between plaque and gingival indexes were found in both groups. However, a stronger correlation between total plaque and gingival index was observed in the adults (M Total PI x M Total GI, $r=0.7393$ ) 
than in the children (C Total PI x C Total GI, $\mathrm{r}=0.5978$ ).

The correlation of Plaque and Gingival Indexes between the pairs of mother/child analyzing selected groups of teeth (Incisors or Molars) or all teeth (TOTAL) is shown in Table 3. A significant but weak correlation was shown between Total plaque index from children and their mothers (C Total PI x M Total PI, $r=0.3895)$. However, a higher correlation in plaque index for the region of first molars between both groups was demonstrated (C Molars PI x M Molars PI, $r=0.5115$ ). No significant correlation between mother and child was obtained by analyzing the gingival index.

The distances CEJ-ABC were measured to detect alveolar bone loss. Children exhibited no bone loss, as evidenced by measures of CEJ-ABC of less than 3mm in every tooth examined (mean value $=1.22 \mathrm{~mm} \pm 0.28$ ). Eighteen out of 30 (60\%) mothers presented at least one value of CEJ-ABC higher than 3mm. CEJ-ABC distance values higher than $5 \mathrm{~mm}$ were observed only in 3 subjects in the mothers group (10\%). No correlation between gingival index in children and alveolar bone loss in mothers was detected $(r=-0.071, p=0.7079)$.

The reported behavioral and social factors were correlated to plaque and gingival indexes of children and their mothers.

TABLE 1- Mean values of plaque and gingival indexes of children and mothers for incisors, first permanent molars and total teeth

\begin{tabular}{|c|c|c|c|c|c|}
\hline & & $\mathrm{Pl}^{*}$ & & $\left.\mathrm{G}\right|^{* *}$ & \\
\hline \multirow{3}{*}{$\begin{array}{c}\text { Children } \\
n=30\end{array}$} & Incisors & 1.38 & \pm 0.57 & 1.24 & \pm 0.41 \\
\hline & Molars & 1.77 & \pm 0.41 & 1.58 & \pm 0.45 \\
\hline & Total & 1.43 & \pm 0.41 & 1.36 & \pm 0.39 \\
\hline \multirow{3}{*}{$\begin{array}{c}\text { Mothers } \\
n=30\end{array}$} & Incisors & 1.38 & \pm 0.48 & 1.32 & \pm 0.46 \\
\hline & Molars ${ }^{\text {*n* }}$ & 1.56 & \pm 0.41 & 1.51 & \pm 0.40 \\
\hline & Total & 1.43 & \pm 0.45 & 1.38 & \pm 0.37 \\
\hline
\end{tabular}

*Mean value of Plaque Index \pm standard deviation ** Mean value of Gengival Index \pm standard deviation $\star \star \star n=27$

TABLE 2- Pearson's correlation between the variables incisors, molars and total teeth considering the plaque $(\mathrm{PI})$ and gingival indexes $(\mathrm{GI})$ of children $(\mathrm{C})$ and mothers (M)

\begin{tabular}{lccc}
\hline \multicolumn{1}{c}{ Correlation } & $r$ & $n$ & $p$ \\
\hline C Incisor PI × C Incisor GI & 0.5826 & 30 & 0.0007 \\
C Molar PI × C Molar GI & 0.5266 & 30 & 0.0028 \\
C Total PI × C Total GI & 0.5978 & 30 & 0.0005 \\
\hline \hline M Incisor PI × M Incisor GI & 0.7620 & 27 & 0.0100 \\
M Molar PI x M Molar GI & 0.4870 & 30 & 0.0000 \\
M Total PI $\times$ M Total GI & 0.7393 & 30 & 0.0000 \\
\hline
\end{tabular}

The data obtained between these reported variables and Total Plaque Index and in Total Gingival Index the mothers group are shown in Table 4. The variables that were associated to mother's plaque index were mother's age, frequency of flossing and the fact of having a job. The fact of having a job was the only significant variable that was associated to gingival index in the group of mothers.

The reported behavior and social status were also correlated to clinical indexes in children, and the results are shown in Table 5. Plaque Index in the children was correlated to variables such as mother's frequency of flossing, mother's support during child's toothbrushing and mother's having a job. Children's Gingival Index was correlated to the variables mother's frequency of flossing, mother with a job, children's frequency of tooth brushing and children's age.

\section{DISCUSSION}

Periodontal conditions in children have been a subject of researches for decades (Bimstein and Ebersole ${ }^{4}$, 1989; Matsson $^{13}$, 1978; Matsson and Goldberg ${ }^{14}$, 1985; Parfit $^{17}$, 1957; Peretz, et al. ${ }^{19}$, 1996; Ramberg, et al. ${ }^{21}$, 1994). However, very little is known about the correlation between the presence of periodontal disease in mothers and the establishment of gingival or periodontal disease in their children.

The influence of the family in the establishment of a pathogenic microbiota in children has been very well

TABLE 3- Pearson's correlation between the pairs of children (C) and mothers (M) when variables of plaque and gingival indexes for total, molars and incisors teeth are considered

\begin{tabular}{lccl}
\hline \multicolumn{1}{c}{ Correlation } & $r$ & $n$ & $p$ \\
\cline { 2 - 4 } C Incisors PI X M Incisors PI & 0.3090 & 30 & 0.0966 \\
C Molars PI X M Molars PI & 0.5115 & 27 & $0.0064^{*}$ \\
C Total PI X M Total PI & 0.3895 & 30 & $0.0334^{* *}$ \\
& & & \\
C Incisors GI X M Incisors GI & 0.3398 & 30 & 0.0662 \\
C Molars GI X M Molars GI & 0.2428 & 27 & 0.2224 \\
C Total GI X M Total GI & 0.3302 & 30 & 0.0747 \\
\hline
\end{tabular}

TABLE 4- Covariance analyses for mother's total plaque and gingival indexes

\begin{tabular}{lll}
\hline \multicolumn{1}{c}{ Variables } & $\mathrm{PI}$ & $\mathrm{GI}$ \\
\hline Age & $0.0014^{*}$ & 0.1261 \\
Frequency of toothbrushing & 0.7633 & 0.8279 \\
Frequency of flossing & $0.0022^{*}$ & 0.1126 \\
School edu cation & 0.0682 & 0.7981 \\
Job & $0.0058^{*}$ & $0.0085^{*}$ \\
Declared family income & 0.1250 & 0.1330 \\
\hline
\end{tabular}

*Statistically significant $(p<0.01)$ 
documented (Könönen, et al. ${ }^{8}$; 1994; Morinushi, et al. ${ }^{16}$, 2000). However, other factors such as hereditary immune response and behavioral factors including tooth cleaning habits should also contribute for the increased prevalence of periodontal disease in certain families.

In the present study, a very homogeneous population with a well-limited age range was analyzed, differing from other studies in the literature (Beaty, et al. ${ }^{3}$, 1993; Zambon, et al. $\left.^{26}, 1983\right)$.

Lower correlation values between plaque and gingival indexes were obtained in the group of children than in the group of mothers. These findings are in agreement with Matsson and Goldberg ${ }^{15}$ (1986) who reported less gingival inflammation in children than in adults in the presence of similar amounts of plaque accumulation, indicating a difference in the pathogenic potential of dental plaque or in the host response.

Significant correlation of plaque between mother-child was found only when "Total" (low correlation) or "Molar" (moderate correlation) plaque index was considered (Table 3). The significant correlation for plaque index in molar region but not significant in the region of incisors may represent different abilities of plaque removal between mothers and children. In the children's group, the eventual absence of proximal contact in the region of incisors may have also contributed to a lower plaque index. Although the oldest children did not show the highest values for plaque accumulation, they exhibited the highest total gingival index values, indicating an increase in gingival reaction to dental plaque accumulation with age, as described in the literature (Bimstein and Matsson ${ }^{5}$, 1999; Matsson ${ }^{13}$, 1978; Matsson and Goldberg ${ }^{15}$, 1986).

There was no correlation between CEJ-ABC distance and plaque or gingival indexes among mothers. Only 3 subjects in the mothers group presented distances values higher than $5 \mathrm{~mm}$. Other studies have also reported that supragingival plaque accumulation was not directly related to alveolar bone loss. In addition, preventive measures alone, aiming to control plaque accumulation, might not be effective in controlling destructive periodontal disease (Albandar, et al. ${ }^{1}$, 1995; Bartold, et al. ${ }^{2}$, 1998).

Declared family income or the socioeconomic class did not influence the oral health of the groups, in contrast to the results found in other studies (MacGregor, Baldin ${ }^{11}$, 1991;

TABLE 5- Covariance analyses for children's total plaque and gingival indexes

\begin{tabular}{lcl}
\hline \multicolumn{1}{c}{ Variable } & $\mathrm{PI}$ & $\mathrm{Gl}$ \\
\hline Mother's frequency of flossing & $0,0143^{*}$ & $0.0124^{*}$ \\
Mother with a job & $0,0105^{*}$ & $0.0105^{*}$ \\
Children's toothbrushing alone or with help & $0,0058^{* *}$ & 0.0663 \\
Children's frequency of toothbrushing & 0,4393 & $0.0009^{* *}$ \\
Children's age & 0,7949 & $0.0105^{*}$ \\
\hline
\end{tabular}

${ }^{*} p<0.01$

${ }^{* *} \mathrm{p}<0.05$
Tan, et al. $\left.{ }^{23}, 1981\right)$. Although the social class was not homogeneous in the study group, it should be noticed that these subjects were seeking free treatment at the University.

Mothers' total gingival index was influenced by the fact of having a job. Those who reported that they worked outside home presented the lowest values for total gingival index. The reduced plaque and gingival indexes in these mothers may reflect an increased self-esteem, need for a better appearance and possibility of getting more information than those at home. A lower total plaque index in the group of children was also demonstrated when their mother reported having a job. These data contribute to the findings that dental health behavior appears to be a part of a person's lifestyle and a significant association between self-esteem and toothbrushing frequency has already been reported (MacGregor and Baldin ${ }^{11}$, 1991).

Regardless almost all parents usually consider tooth brushing as important for oral health, only 11 mothers reported helping the children in their oral hygiene. A lower total plaque index in the group of children was demonstrated when the mothers helped the children to brush their teeth. As expected, parents' supervision improved the quality of tooth cleaning. A Dutch study pointed out that a quarter of 12 years-old children were not supervised in their oral home care (Petersen $\left.^{20}, 1992\right)$. In countries where high levels of caries reduction were achieved such in Denmark, three-quarters of the parents of 6 years old children answered that they believed children less than 10 years old need help from adults in toothbrushing (Petersen ${ }^{20}$, 1992).

Total gingival index was decreased with an increase in frequency of children's tooth brushing and when their mothers declared they are used to flossing everyday. Children's plaque index was also reduced when their mothers answered that they flossed "always", showing that mother's frequency of flossing may reflect their awareness of the importance of oral hygiene, which could be transmitted and stimulated in the children. It has been long before when it was reported that children follow the example of their parents. Therefore, it is more effective to change behavior through the route of behavior itself than through the route of knowledge. This information may be also useful to be aware that it is not very effective to direct the efforts in dental health education solely to the youngsters (Tan, et al. ${ }^{23}, 1981$ ).

Although no clinically significant correlation in plaque or periodontal indexes between mothers and their children could be found, mothers awareness to oral health, represented by flossing and attention to child's oral hygiene, was significantly correlated to children's better oral health. These data reinforce the need for family participation in oral health campaigns and not only school-based programs.

\section{REFERENCES}

1- Albandar JM, Buischi YAP, Oliveira LB, Axelsson P. Lack of effect of oral hygiene training on periodontal disease progression over three years in adolescents. J Periodontol. 1995;66:255-60. 
2- Bartold GJ, Syemour MP, Cullinan MP, Westerman B. Effect of increased community and professional awareness of plaque control on the management of inflammatory periodontal diseases. Int Dent $\mathrm{J}$. 1998;48:282-9

3- Beaty TH, Colyer CR, Chang YC, Liag KY, Graybeal JC, Muhammad NK, et al. Familial aggregation of periodontal indices. J Dent Res. 1993;72:544-51.

4- Bimstein E, Ebersole JE. The age-dependent reaction of periodontal tissues to dental plaque. J Dent Child. 1989;56:358-62.

5- Bimstein E, Matsson L. Growth and development considerations in the diagnosis of gingivitis and periodontitis in children. Pediatr Dent. 1999;21:186-91.

6- Bimstein E, Ram D, Naor R, Sela MN. The composition of subgengival microflora in two groups of children with and withou primary dentition alveolar bone loss. Pediatr Dent 1996;18:42-7.

7- Caufield PW, Cutter GR, Dasanayake AP. Initial acquisition of mutans streptococci by infants: evidence for a discrete window of infectivity. J Dent Res. 1993;72:37-45.

8- Könönen E, Saarela M, Karjalainen J, Jousimies-Somer H, Alaluusua S, Asikainen S. Transmission of oral Prevotella melanonogenica between a mother and her young child. Relationship between oral gram negative anaerobic bacteria in saliva of mother and the colonization of her edentulous infant. Oral Microbiol Immunol. 1994;9:310-4.

9- Li Y, Caulfield PW. The fidelity of initial acquisition of mutans streptococci by infants from their mothers. J Dent Res. 1995;74:6815.

10- Löe H, Silness P. Periodontal disease in pregnancy I. Acta Odontol Scand. 1963;21:533-51.

11- MacGregor IDM, Baldin JW. Self-esteem as a predictor of tooth brushing behavior in young adolescents. J Clin Periodontol. 1991;18:312-6.

12- Mackler SB, Crawford JJ. Plaque development and gingivitis in the primary dentition. J Periodontol. 1973;44:18-24.

13- Matsson L. Development of gingivits in pre-school children and young adults. J Clin Periodontol. 1978;5:24-34.

14- Matsson L, Goldberg P. Gingival inflammatory reaction in children at different ages. J Clin Periodontol. 1985;12:98-103.

15- Matsson L, Goldberg P. Gingival inflammation at deciduous and permanent teeth. J Clin Periodontol. 1986;13:740-2.

16- Morinushi T, Lopatin DE, Poperin NV, Ueda Y. The relationship between gingivitis and colonization by Porphyromonas gingivalis and Actinobacillus actinomycetemcomitans in children. J Periodontol. 2000; 71:403-9

17- Parfitt GJ. A five year longitudinal study of the gingival conditions of a group of children in England. J Periodontol. 1957;28:26-32.

18- Peretz B, Machtei EM, Bimstein E. Changes in periodontal status of children and young adolescence: a one-year longitudinal study. J Clin Pediatr Dent. 1993;18:3-6.

19- Peretz B, Machtei EM, Bimstein E. Periodontal status in childhood and early adolescence: three-year follow up. J Clin Pediatr Dent. 1996;20:229-32.

20- Petersen PE. Oral health behavior of 6-year-old Danish children. Acta Odontol Scand. 1992;50:7-64
21- Ramberg PW, Lindhe J, Gaffar A. Plaque and gingivitis in the deciduous and permanent dentition. J Clin Periodontol. 1994;21:4906.

22- Silness P, Löe H. Periodontal disease in pregnancy II. Acta Odontol Scand. 1964;22:121-6.

23- Tan H, Ter Horst G, Dekking YM. Dental knowledge, attitude and behavior in 12-year-old dutch suburban children. Community Dent Oral Epidemiol. 1981;9:122-7.

24- Theilade E, Wright WH, Jensen SB, Löe H. Experimental gingivitis in man. II. A longitudinal clinical and bacteriological investigation. J Periodontal Res. 1966;1:1-13.

25- Von Troil-Lindén B, Torkko H, Alaluusua S, Wolf J, JousimiesSomer H, Asikainen S. Periodontal findings in spouses - A clinical, radiographic and microbiological study. J Clin Periodontol. 1995;2:939

26- Zambon JJ, Christersson LA, Slots J. Actinobacillus actinomycetemcomitans in human periodontal disease. Prevalence in patient groups and distribution of biotypes and serotypes within families. J Periodontol. 1983;54:707-11. 